A Journal of Culture, English Language, Teaching \& Literature ISSN 1414-3320 (Print), ISSN 2502-4914 (Online)

Vol. 19 No.2; December 2019

Copyright $\odot$ Soegijapranata Catholic University, Indonesia

Direct and Indirect Compliment Responses: A Descriptive Qualitative Study among Indonesians and Americans

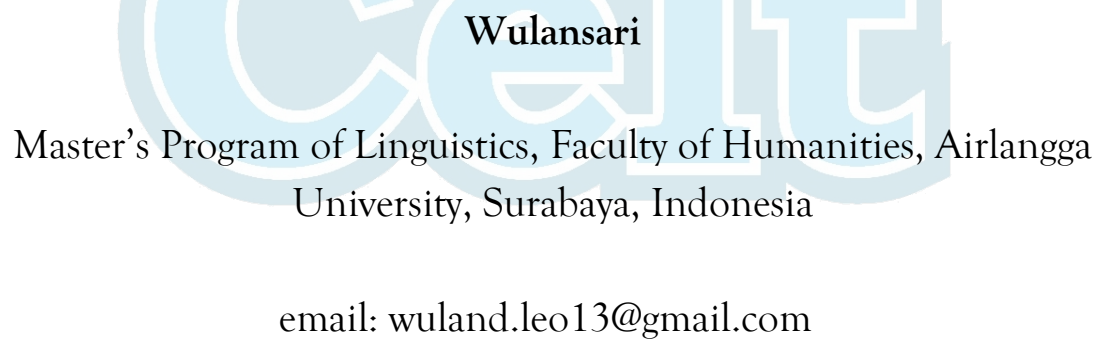

Received: 26-12-2019 Accepted: 01-01-2020 Published: 06-06-2020 


\title{
Direct and Indirect Compliment Responses: A Descriptive Qualitative Study among Indonesians and Americans
}

\author{
Wulansari \\ wuland.1eo13@gmail.com \\ Master's Program of Linguistics, Faculty of Humanities, \\ Airlangga University, Surabaya, Indonesia
}

\begin{abstract}
Indonesians and Americans have the strategies to respond the compliment which came from different culture. The aims of this research were addressing types of strategies and disclosing the direct and indirect response used by the Indonesians and Americans to respond the compliments. The research data consist of English and Indonesian. The data was analyzed by using qualitative method. The Discourse Completion Test (DCT) questionnaire was used to know the differences between compliment response given to Indonesians and Americans. The result of the research showed that the (1) responded category of Holmes (1986) classification of compliment responses strategies (CRs) are using three strategies (accept, reject and evade) among Indonesians and Americans. Indonesians tended to accept, reject and evade compliment by giving some reasons. While Americans tended using three categories by saying, "thank you" due to express of openness and receiving appreciation from the interlocutor. (2) The existence of culture plays an important role in responding compliment towards Indonesians and Americans. The Americans respond to compliments direct response and simple answers to compliments. Meanwhile, Indonesians prefer to respond compliment with indirect responses because they were leaning on the principle known as saving face politeness.
\end{abstract}

Key words: compliment responses, Discourse Completion Test (DCT), cultural differences

Abstrak: Orang Indonesia dan Amerika memiliki strategi untuk merespons pujian yang berasal dari budaya yang berbeda. Tujuan dari 
penelitian ini adalah membahas jenis strategi dan mengungkapkan tanggapan langsung dan tidak langsung yang digunakan oleh orang Indonesia dan Amerika untuk menanggapi pujian. Data penelitian terdiri dari Bahasa Inggris dan Bahasa Indonesia. Data dianalisis dengan menggunakan metode kualitatif. Proses kuesioner DCT digunakan untuk mengetahui perbedaan antara respon pujian yang diberikan kepada orang Indonesia dan orang Amerika. Hasil penelitian menunjukkan bahwa (1) kategori Holmes (1986) klasifikasi strategi merespons pujian (CRs) menggunakan tiga strategi (menerima, menolak dan menghindari) antara orang Indonesia dan Amerika. Orang Indonesia cenderung menerima, menolak dan menghindari pujian dengan memberikan beberapa alasan. Sementara orang Amerika cenderung menggunakan tiga kategori dengan mengatakan, "terima kasih" karena menyatakan keterbukaan dan menerima penghargaan dari lawan bicaranya. (2) Keberadaan budaya memainkan peran penting dalam menanggapi pujian terhadap orang Indonesia dan Amerika. Orang Amerika menanggapi pujian tanggapan langsung dan jawaban sederhana untuk pujian. Sedangkan, orang Indonesia lebih suka menanggapi pujian dengan tanggapan tidak langsung karena mereka bersandar pada prinsip yang dikenal sebagai menyelamatkan wajah kesopanan.

Kata kunci: tanggapan pujian, Uji Penyelesaian Wacana (DCT), perbedaan budaya

\section{INTRODUCTION}

Language is a tool of human interaction in everyday lives and cooperates with each other for communication. Another point, language also is used for expressing their feeling to others (Wierzbicka, 1996). Understanding conversation is an oral interaction with face to face between two or more participants and more than just exchanging. Language plays a vital role in determining of communication between people and others. On other hand, language has relation with culture because different culture will have different language of interaction. People in different cultures might misunderstand each other because they express differently and might misread what others have said (Fujimura-wilson, 1991). Communications occur within social contexts and are defined by societal forces, assessing the context in which responses occur is imperative to identifying the processes influencing communications. The use and understanding of language is usually studied by pragmatics. In addition pragmatics is also learned about human interaction 
(Wierzbicka, 2003). Learning pragmatics, the "rules of speaking" is essential to be successful operation in the language. On other hand, Pragmatics can be seen as a systematic way of explaining how language is used in context. It also deals with particular utterances in particular situations, and is especially concerned with various ways in which many social contexts can influence how language is used (Thomas, 1983). Besides that, he also stated that context refers to the real situation, background or environment relevant to a particular event, personality, and creation. In addition, according to Barkindo (2013) pragmatists has attributed great importance to the study of speech act behavior, such as apology, request, compliments, refusal, and complaint. The social situational factors occur due to the use of speech act, those are age, gender, education, social distance, social relationship, style, and ethnicity.

Herbert (1990) stated that the speech event of complimenting is discussed to be generally structured as approach in a way that someone compliments and people usually respond to what they said. Complimenting is commonly applied in a way to make people feel good; meanwhile, in another culture of complimenting might connote the speaker's willingness towards the addressee's belonging, being reacted against via the recipient's offering the object of compliment and possibly leading to embarrassment to a speaker from a different culture (Allami \& Montazeri, 2012). Different culture will produce different role. Therefore, compliments and compliment responses have been expressed as highly formulaic speech act (Wolfson \& Manes, 1980). According to (Holmes, 1988) showed that a proper complimenting behavior can make people getting closer. The closer of relationship the more polite of response is given and the responses to the compliment vary due to the social and individual elements. It can be from different cultural customs, communicative topics, social power and gender etc. A compliment is defined as "a speech act which explicitly or implicitly attributes credit to somebody other than the speaker and usually the person addressed for some good; possession, characteristic and skill (Holmes, 1988). The compliment event is an adjacency pair operation which it consists of two parts: the compliment and the compliment response (Sacks \& Schegloff, 1973).

In recent years, the phenomena of compliment responses with different cultural background have been investigated by many researchers both international and national. The factors affecting the compliment responses was investigated in the German, Zulu, Iran and Arab (see Golato,2002; Annatius, 2005; Razi, 2013; Falasi, 2007). They conducted how compliment responses can be used in a variety of social situations which among others, includes: parties, evening receptions, graduation ceremonies, etc. 
Compliments responses can be used in appearance and many others. They used the concept of Discourse Completion Task (DCT) conducted in collecting the data. In addition, in the context of Indonesian researcher, only one related study and method of the research was available. These studies were focused on compliment and compliment responses to classify the different culture among Indonesian people (see Refnaldi, 2009; Rachman et al, 2018; Maulida, 2019). Nevertheless, despite present popularity and factors of those studies in complement response and good result of their research, a lack of knowledge and exploration on comparing culture between Indonesian and other countries in which their studies were focused on Indonesian culture. For this reason, the overarching goal of this study is to address this gap. This study aims to investigate the compliment response among Indonesian and American.

\section{LITERATURE REVIEW}

\section{A. Speech Act}

Speech act theory shows a core role in the field of pragmatics (Vaneva \& Ivanovska, 2018). Speech acts are significant in the process of foreign language learning as foreign language learners should be able to know what language structures and vocabulary to use in a certain context. Every culture has its own repertoire of characteristic speech acts and speech genres (Wierzbicka, 2003). (Searle, 1976) described that direct speech acts are showed as utterances in which the sentence meaning of the utterance is consistent with what the speaker intends to accomplish (speaker meaning). (Austin, 1962) introduced the "doctrine of illocutionary forces" that focuses on the performative linguistic function in which speech is regarded as action. In addition, the utterance that speaker produces conveys three layers (locutionary acts, illocutionary acts, and perlocutionary acts) of meaning interrelated to one another: the literal meaning of the utterance produced by the speaker, the speaker's intention conveyed in the utterance, and the effect that the utterance has on the hearer.

\section{B. Compliment Response}

The result of study by Pomerantz (1978) discussed that compliments are very common in daily life and usually intended to make others feel good. In every culture has different of giving compliments response. It can be agreement, disagreements, upgrades, downgrades and referent shifts. This 
100 Celt: A Journal of Culture, English Language Teaching \& Literature, Volume 20, Number 1, June 2020, pp. 96 - 116

means that the important thing is they are explicit, and that they force the speaker to be explicit and to make clear analytical decisions. For example, a term such as 'upgrade' may seem intuitively intelligible, but it does not make it clear whether it is meant to apply only to a substitution of 'very good' for 'good', or whether it is also meant to stand for a substitution of 'very bad' for 'bad', or 'good' for 'not bad'. Thus, Holmes (1988) argues compliments show to be functionally complex speech acts such as solidarity signals, commenting on friendships and attenuating demands. He also claimed that claims that compliment responses seem to express from the hearer acknowledge the kindness or to offer the compliment. Compliments are the type speech act and relate to politeness in which it can appear the good or bad response (Lorenzo-Dus, 2001). For instance the compliments can attend positive politeness by giving positive comments or can cause embarrassment to interlocutors, including a face-threatening act. (Pomerantz, 1978) investigated compliment responses and stated that some conditions need to be achieved, which are agreement and acceptance.

\section{Directness Indirectness}

These terms are often used in linguistic description. Direct relates with something to the point while Indirect is used imperatives. For instance if someone says "close the door!" it means direct and says "could you close the door?" it is indirect (Wierzbicka, 2003). (Searle, 1976) showed that indirect speech acts, such a relation need not exist. It means that sentence meaning and speaker meaning may be different. For example, a speaker may utter the sentence "Can you reach the book?" and the mean is not a question, but it is request to take the book. Another example showed between American culture and Israeli culture. According to (Blum-kulka \& Olshtain, 1984) stated that the level of directness in Israel society is high due to influence from Hebrew, while in English using an interrogative-directive device.

The combination of the imperative with some interrogative features in common English directives (Wierzbicka, 2003). According to (Wierzbicka, 2003) determine Javanese society do not want others to know what they feel or to restrain not only the external expression of feelings, but also internal emotional experience. In addition, Javanese people rarely use direct speech to express something, whether in the form of a request, disapproval, or a will. The Javanese have the habit of speaking indirect, that is, people will not show their true feelings (Rachman et al., 2018) 


\section{Cross Cultural Studies}

The latest research of (Wierzbicka, 2003) shows anyone who has lived in different countries where people speak in different ways, she states not only because they use different linguistic codes, involving different lexicons and different grammars, but also because their ways of using the codes are different. It can be seen, (Kochman, 1981) has shown that in Black American culture the norm of 'modesty' does not apply, and that self-praise is not viewed negatively at all. Thus, (Honna et al,. (1989) point out that 'praise of other' is seen as arrogant and presumptuous in Japanese culture, where the speaker has or wants to express his praise for persons within his circle, he often begins with a phrase such as "I don't really mean to praise" or "I know it is too presumptuous to praise". It means that he is not really an arrogant person. Then, all societies view of praise of self negatively, and praise of other positively. The points to the conclusion that different culture in the study of language evaluate (1) in different societies and communities, people speak differently. (2) These differences in ways of speaking are profound and systematic. (3) These differences reflect different cultural values, or different hierarchies of values. (4) Different ways of speaking, different communicative styles can be explained and made sense of, in terms of independently established different cultural values and cultural priorities (Wierzbicka, 2003). Looking at those reasons, this study comes to investigate the compliment response among Indonesian and American.

\section{E. Cultural differences among Indonesian and American}

The differences in cultural backgrounds or cross culture background between Indonesia and other countries make various people's language behavior. The latest research (Rachman et al., 2018) evaluate that the expression of compliment for the society has important function due to create harmony in social relationships. Compliment response of some people in certain cultures in Indonesia or other countries have different role. Hence, another study on the topic by (Brown \& Levinson, 1988) assert that responding of compliments by saying "thank you" or approving the compliment can be considered arrogant while rejecting a compliment is a violation. In addition, according of this theory, compliment response of western culture, by accepting compliment someone has provided the means to accommodate the positive face of response. In other words, by accepting the compliment, it means that they respect and appreciate the compliment for agreeing that what they say of complimenting is true and good pray. The difference theory of language adopted by Western and Indonesian culture 
102 Celt: A Journal of Culture, English Language Teaching \& Literature, Volume 20, Number 1, June 2020, pp. 96 - 116

raises the question which rejecting complaint for certain societies is an act of polite communication. However, in Indonesia, certain circles have experienced a slight shift (Rachman et al., 2018). They also found that in certain groups, namely a group of changes consisting of students and people who works in the entertainment industry tend to experience a shift. The groups of change that have been influenced by Western cultures have begun to respond of compliment by receiving it like Western societies. In this study, the concept of compliment response is, therefore, proposed. The different culture of compliment response is to understand every culture or not wrong to response the compliment.

\section{F. Compliment Response Framework}

As has been highlighted by Wierzbicka (2003), people talk and communicate with different styles. These differences reflect different cultural values. This culture becomes a part of communication behavior. After which this communication plays a role in determining, maintaining, developing or passing down culture. Every culture has different value systems. Therefore understanding how to communicate in a good way is very important. Talking about how to communicate cannot be separated from the language, rules and norms.

In addition, understanding intercultural communication will overcome cultural barriers to connect with others, so that we will be rewarded for human needs, aspirations and feelings. For example, when Indonesians meet Americans, because Indonesians see American's beauty, Indonesians do some compliments, or they do the same compliments. What response should we give, and how should we respond of compliment. Thus, understanding compliments and how to respond to compliments are needed in which they are not wrong in their attitude.

Based on the above theoretical framework, the research problems are formulated as follows:

1. What are the types of Compliment response between Indonesian and American?

2. What are the differences in compliment responses between Indonesian and American people? 


\section{METHOD}

To collect the data, I used the qualitative data since I want to get a clear result on the subjects' pragmatic competence. Hence, the study employed the Discourse Completion Tasks or Discourse Completion Tests (DCTs). According to Refnaldi (2009) stated that Although DCT has a number of weaknesses, the use of this test provides several advantages. The use of DCT has been able to express what the speaker thinks and what he will convey verbally in the context of the same situation.

The use of DCT is effective for the following purposes: obtaining large amounts of data quickly, making imitations of natural expressions in natural situations, gaining an understanding of possible cultural and psychological conditions influences expressions, and ensuring in general the various forms and variations of the compliment response.

The data were analyzed using criteria raised by Holmes (1988) classified compliment response strategies (CRs) into three main acts: Accept, Reject, and Evade; each strategy has some subdivided strategies, Accept (Appreciation Token, Comment Acceptance, Praise Upgrade), Reject (Disagreeing Utterances) and Evade (Return). The aims of this study are to investigate the differences among Indonesian and America speakers using CRs.

\section{A. Type of Research}

This research was conducted by using qualitative method because the problems related to humans are fundamentally dependent on observation. Qualitative approach is an approach that is carried out in full to the subject of research where there is an event where the researcher becomes a key instrument in research, then the results of the approach are described in the form of words written empirical data that has been obtained and in this approach also emphasizes the meaning rather than generalization (Muhammad, 2013)

\section{B. Research Subjects}

The research participants for this study are from Indonesia and America. There were 20 participants; there are 10 participants of each country as subjects for the research. 
104 Celt: A Journal of Culture, English Language Teaching \& Literature, Volume 20, Number 1, June 2020, pp. 96 - 116

The reason for having those participants from Indonesia and America was to determine the compliment response when they get praise. Therefore, we can know the correct strategies that they used.

\section{Research Procedure}

The Discourse Completion test (DCT) given in Indonesian and in English. The instrument data was using Google form in the form of questionnaire. This is necessary in order to get the data quickly and easily. In the DCT there are some questions.

The questions consist of name, email, country where they are from, and one main question "if someone says you are pretty or handsome. What do you usually respond?". Those questions exist in English and Indonesian. They may answer in Indonesian or English. Then the researcher shared the link to social media (Instagram, Facebook, WhatsApp) in which they are friend.

On other hand, the researcher asked her friend to share the link in all of their social media and asked the participants to complete the questions. The researcher investigated the result whether direct or indirect compliment response giving among Indonesian and America.

\section{RESULTS AND DISCUSSIONS}

\section{A. Results}

The results of this study provide information of how Indonesian and American response the compliment, according to Holmes, 1988 taxonomy of CR strategies was used to make a contrastive analysis of CRs among Indonesia and American speakers. Using these strategies, the data were easily classified. The comparison of compliment responses delivered among Indonesian and American people for each category can be seen in the following table:

Table 1:

The percentage of Response Strategies in Compliments between Indonesians and Americans

\begin{tabular}{cccc}
\hline $\begin{array}{c}\text { Type of } \\
\text { Response }\end{array}$ & CRs & Indonesian & American \\
\hline & Appreciation Token & $10 \%$ & $60 \%$ \\
\hline
\end{tabular}




\begin{tabular}{llll}
\hline Accept & Comment Acceptance & $20 \%$ & - \\
\hline & Praise Upgrade & $10 \%$ & $10 \%$ \\
\hline Reject & Total of Accept & $40 \%$ & $70 \%$ \\
& $\begin{array}{l}\text { Disagreeing } \\
\text { Utterances }\end{array}$ & $30 \%$ & $20 \%$ \\
\hline Evade & Return & $30 \%$ & $10 \%$ \\
\hline
\end{tabular}

As shown in table 1 , it showed the data about the number of compliment responses which was delivered by Indonesian and American. Concerning to the first research question, the result of this study presented that there were three types of responses and five response strategies investigated, the category of accept gets the highest percentage, those are $40 \%$ of Indonesians compliment responses includes in the category of receiving the compliment accept, with details of 10\% appreciation token with pride, $20 \%$ comment acceptance, and $10 \%$ received the compliment by praising people who gave it back or Praise upgrade.

The second, the reject category, there are $30 \%$ of disagreeing utterances. The last category, $30 \%$ of evade by return response, it means the compliment is delivered but avoids it given. While the results of the praise response given by Americans, $70 \%$ of accept, the responses are received.

Despite having the highest percentage like Indonesia, Americans have almost twice the higher results, with details of $60 \%$ appreciation token by directly expressing "thank you", and $10 \%$ receiving by praising upgrade, while there is no result showing the category of giving comments or comment acceptance. The last category is rejecting that is $20 \%$ of disagreeing utterances and $10 \%$ of evade in which they give smile.

Table 2:

The Result of Compliments Response of Indonesians

\begin{tabular}{|c|c|c|}
\hline $\begin{array}{l}\text { Types of } \\
\text { Response }\end{array}$ & CRs & Complement response \\
\hline \multirow[t]{2}{*}{ Accept } & $\begin{array}{l}\text { Appreciatio } \\
\mathrm{n} \text { Token }\end{array}$ & $\begin{array}{l}\text { 1. "Off course, Yes I'm, because I am pretty, } \\
\text { beautiful and absolutely gorgeous" }\end{array}$ \\
\hline & $\begin{array}{l}\text { Comment } \\
\text { Acceptance }\end{array}$ & $\begin{array}{l}\text { 2. "I will say amen, Alhamdulillah and } \\
\text { thank you, I am amused because I feel } \\
\text { not so beautiful and I say amen hopefully }\end{array}$ \\
\hline
\end{tabular}


106 Celt: A Journal of Culture, English Language Teaching \& Literature, Volume 20, Number 1, June 2020, pp. 96 - 116

\begin{tabular}{|c|c|c|c|}
\hline & & & $\begin{array}{l}\text { Allah granted that person's words, do not } \\
\text { forget I say Alhamdulillah as gratitude to } \\
\text { Allah and thank you". } \\
\text { "MashAllah, all were because of Allah, } \\
\text { the God who created us. I respond by } \\
\text { thanking God, then thanking the praise } \\
\text { giver. Delivering that beauty is not } \\
\text { limited in physical view, but also inner- } \\
\text { beauty which is reflected in people's } \\
\text { behavior and character". }\end{array}$ \\
\hline & $\begin{array}{l}\text { Praise } \\
\text { Upgrade }\end{array}$ & 4. & "Thank you. You are a lot prettier" \\
\hline Reject & $\begin{array}{l}\text { Disagreeing } \\
\text { Utterances }\end{array}$ & $\begin{array}{l}5 . \\
6 .\end{array}$ & $\begin{array}{l}\text { "Ah no. You are more beautiful or } \\
\text { handsome than me" } \\
\text { "Ignore and don't care about the } \\
\text { compliment, because I feel not } \\
\text { handsome" } \\
\text { "Immediately refused the compliment, } \\
\text { and said that she, the one who said, was } \\
\text { more beautiful because basically I was } \\
\text { not confident." }\end{array}$ \\
\hline Evade & Return & $\begin{array}{l}9 . \\
10\end{array}$ & $\begin{array}{l}\text { "Really? Say thank you. because they } \\
\text { praise me" } \\
\text { "Smile and say it back" } \\
\text { "Usually I will shrug off the compliment, } \\
\text { so that it gives the impression of being } \\
\text { modest. Then I added by praising him } \\
\text { back." }\end{array}$ \\
\hline
\end{tabular}

Based on the results of data analysis contained in table 2 above, it was found that the strategy used in the response was the indirect response, because Indonesians were responded by giving reasons. Furthermore, when viewed from the form of responses given, Indonesians rarely respond to praise by simply saying thank you, but the word "thank you" will be followed by comments. The results of the token appreciation showed that the response to praise was expressed with confidence by receiving highly praise. Comment acceptance starts with an expression of gratitude and was followed by comments that gave appreciation to those who praised it. Praise update was 
almost the same as comment acceptance but praise update gives praise back to the speaker.

In the eastern culture, especially in Indonesia had different way in responding the compliment. Most of them responded the compliment with rejection or evade to give respectful or modesty responses and to minimize the praise which was given to them. Rejection responses by Indonesian didn't mean that they disrespected the speaker or the one who gave compliment. It showed that Indonesian had the own way to response the compliment and to honor the speaker. Eastern culture prioritizes harmonious relations, shame, and self-image, for instance the Javanese.

According to Rachman et al. (2018) discuss the Javanese is a group who is well known for getting along well. So, Javanese people rarely use direct speech to unite something, in the form of requests, responses compliment or disapproval. Furthermore, when compared to Indonesians with responses delivered by Americans who were very significant difference in responding to praise (see table 3 below)

\section{Table 3:}

The Result of Compliments Response of American

\begin{tabular}{|c|c|c|}
\hline $\begin{array}{l}\text { Types of } \\
\text { Response }\end{array}$ & CRs & Complement response \\
\hline \multirow[t]{3}{*}{ Accept } & Appreciation Token & $\begin{array}{l}\text { 1. "I usually say "Thank you" } \\
\text { 2. "Thank you" } \\
\text { 3. "Thank you" } \\
\text { 4. "I say yes and thank you " } \\
\text { 5. "Oh thanks, I showed" } \\
\text { 6. "yeah thank you" }\end{array}$ \\
\hline & Comment Acceptance & \\
\hline & Praise Upgrade & 7. "thank you, you too" \\
\hline Reject & Disagreeing Utterances & $\begin{array}{l}\text { 8. "I brush it off" } \\
\text { 9. "Typically, I become } \\
\text { embarrassed, then say thank } \\
\text { you. I am generally } \\
\text { uncomfortable with praise } \\
\text { about my appearance". }\end{array}$ \\
\hline Evade & Return & 10. "Smile and say thank you" \\
\hline
\end{tabular}


108 Celt: A Journal of Culture, English Language Teaching \& Literature, Volume 20, Number 1, June 2020, pp. 96 - 116

Based on the results of data analysis contained in table 3 above, it was found that the strategy used in the response was the direct response. It can be seen from the response; Americans prefer to respond directly and without reason. They say directly with "thank you". American in responding the compliment they tended to response the compliment by simple response such as "thanks", "thank you" or "yes". It could be seen in table 3 above.

The influence of culture is significantly affected the response of the compliment which was delivered by two groups (American and Indonesian). Whether they used direct or indirect response depended their cultures background. In sum up, every country had unique strategies in responding the compliment. It depended on what the background culture they have.

\section{B. Discussion}

\section{Compliment response with accept}

Receiving is welcoming, taking, justifying, and allowing. In the context of receiving a compliment response, it means that the compliment respondent approves the compliment given. Receiving praise can be realized by three strategies, namely appreciation token, comment acceptance and praise upgrade.

a. "Off course, Yes I'm, because I am pretty, beautiful and absolutely gorgeous” (Indonesian's response)

This response is categorized as appreciation token; it can be seen from the words "off course", "pretty" and "gorgeous". Thus, these words indicated that the respondent felt proud and appreciated the praise given.

b. American's response

- "I usually say "Thank you"

- “Thank you”

- “Thank you”

- I say "yes" and "thank you"

- "Oh thanks, I showed"

- "yeah "thank you” 
These responses are categorized as appreciation token; it can be seen from those words. American people were more likely saying "thank you". It means they appreciated someone who gives compliment.

c. "I will say amen, Alhamdulillah and thank you, I am amused because I feel not so beautiful and I say amen hopefully Allah granted that person's words, do not forget I say Alhamdulillah as gratitude to Allah and thank you". (Indonesian's response)

This response is categorized as comment acceptance; it can be seen from that response used many words of Alhamdulillah and finally said "thank you". She received the compliment by thanking to Allah.

d. "MashAllah, all were because of Allah, the God who created us. I respond by thanking God, then thanking the praise giver. Delivering that beauty is not limited in physical view, but also inner-beauty which is reflected in people's behavior and character". (Indonesian's response)

This response is categorized as comment acceptance; it can be seen by saying "thank you" and giving comment by thanking to Allah. She realized that all were because of Allah who has created us.

e. "Thank you. You are a lot prettier" (Indonesian's response)

This response is categorized as praise upgrade; it can be seen from the words "you are a lot prettier". Despite accepting the compliment, she praised it back to someone who gives the praise.

f. “Thank you, you too” (American's response)

This response is categorized as praise upgrade; it can be seen from the words "you too". Despite accepting the compliment, she gave the compliment back to someone who gives the praise. 
110 Celt: A Journal of Culture, English Language Teaching \& Literature, Volume 20, Number 1, June 2020, pp. 96 - 116

2. Compliment response with reject

The definition of refusing is an act of not accepting, not approving of opinions, and does not justify. While, rejecting praise means not accepting, not approving, and not justifying the praise given. Rejecting the compliment can be illustrated by directly and indirectly. Direct reject means not agreeing to the acceptable praise directly without explanation. Indirect reject means rejection by giving explanation.

a. "Ah no. You are more beautiful or handsome than me" (Indonesian's response)

This response is categorized as disagreeing utterance, because the compliment response is directly "no". This type is included in indirect reject in which there was the rejecting explanation such as praising back.

b. "Ignore and don't care about the compliment, because I feel not handsome" (Indonesian's response)

This response is categorized as disagreeing utterance, because the compliment response ignored the compliment. This type is included in indirect reject in which there was the reason of rejecting explanation.

c. "Immediately refused the compliment, and said that she, the one who said, was more beautiful because basically I was not confident." (Indonesian's response)

This response is categorized as disagreeing utterance; it can be seen from the refusing compliment. The respondent did not feel confident. This type is included in indirect reject in which there was the reason of rejecting explanation.

d. "I brush it off" (American's response)

This response is categorized as disagreeing utterance, because the compliment response declined the compliment. This type is included in direct reject directly in which there was no reason of rejecting explanation. This reason is to strengthen the rejection of the praise given by the friend. 
e. "Typically, I become embarrassed, then say thank you. I am generally uncomfortable with praise about my appearance" (American's response)

This response is categorized as disagreeing utterance, because the response ignored the compliment. This type is included in indirect reject in which there was the reason of rejecting explanation.

\section{Compliment response with Evade}

Evade category is to keep away from praise. This response gives clues such as smiles, shyness or doubt about the compliment. However, this response category still received the compliment.

a. "Really? Say thank you. because they praise me" (Indonesian's response)

This response is categorized as compliment return; it can be seen from the word "really". Thus, that word indicated that the respondent felt doubt and finally saying thank you.

b. "Smile and say it back" (Indonesian's response)

This response is categorized as compliment return. The respondent gave smile which was interpreted as returning the compliment. This category is often used by Indonesian people due to avoid arrogant.

c. "Usually I will shrug off the compliment, so that it gives the impression of being modest. Then I added by praising him back." (Indonesian's response)

This response is categorized as compliment return: it can be seen from the word "shrug off". Thus, the word indicated that the respondent ignored the compliment and appreciated the praise given.

d. "Smile and say thank you" (American's response)

This response is categorized as compliment return. The respondent gave smile which was interpreted as returning 
112 Celt: A Journal of Culture, English Language Teaching \& Literature, Volume 20, Number 1, June 2020, pp. 96 - 116

the compliment. This category meant returning compliment by gesture and saying thank you.

How can we know the differences between Indonesian and American, it can be seen from the data above? The compliment responses were delivered between Indonesian and American having significantly different style. Every country has a certain way of responding compliment depending on its culture and customs. Every society in speech is bound by social values and cultural values, including values when using language. Culture is something that will affect the level of knowledge and information systems or support human thought. Each country certainly has a different culture from each other. An example is the difference between eastern and western cultures. East and West are two different cultures. Eastern culture is a culture that developed in Asia, such as Indonesia, while western culture is a culture that developed in the regions of Europe and America such as the United States.

This study also elicited that beliefs and feelings towards directness and indirectness among eastern and western country were factors that motivated from customs or culture. Indonesian society is an Eastern society which has different customs from Western people. Indonesian people are collective societies while Western people are included in individualist groups (Hofstede, 2010). Collective society is concerned with harmonious relations, shame, and self-image while individualist societies are concerned with personal interests and self-actualization (Hofstede, 2010). In other words, what they believe about different cultures affects the response of compliment to be given.

This study obtains another focal finding on responding the compliment requires a strategy of the utterances which are issued do not threaten the 'face' of the speech partner. Humans have two types of politeness faces, namely 'negative face' and 'positive face'. The desire of individuals not to be blocked by others is called 'negative face' while 'positive face' is the desire of every speaker to be accepted or liked by others. Indonesian society in general tends rejecting compliment for showing politeness. The strategy which was often used was to reject or accept but was accompanied by follow-up comments such as explaining reasons, showing shame, and showing disbelief. This refusal, accompanied by continued comments, reduces the threat to the given of compliment. Meanwhile, Western society usually uses positive politeness when responding compliment by accepting the compliment. Receiving compliments such as saying, "thank you" is an expression of openness and receiving appreciation from the interlocutor. Doing rejection in Western culture is considered to threaten the 'face' of the speech partner. It can be seen from the 
results of the analysis in table 1 which shows that the response to accept Americans had the highest percentage of Indonesians. This finding is in consonance with previous empirical evidences showing the same result which denotes that different cultures will influence compliment response (see Refnaldi, 2009, Herbert, 1988). Furthermore, based on the results of descriptive statistics, this study also found the right conditions in responding to different cultural responses. In the views of Refnaldi (2009), Rachman et al. (2018), the advantage of knowing these different cultures shows the right strategy in responding complement. They felt comfortable and excited about using language because of the diversity of languages in each culture.

\section{CONCLUSION}

This study is to investigate the compliment response among Indonesian and American. This study has revealed how the compliment response can be realized with several strategies. Due to cultural aspects, there have been several differences in responding compliment performed by Indonesian versus American people. First, the data of Indonesian compliment response used accept categories. Receiving compliments was accompanied by giving reasons, for instance expressing gratitude and giving praise back to interlocutors. In addition, they also used the direct and indirect rejection strategy. Indirectly rejection was manifested by reason, feeling shy, humble and expressing insecurity. Second, data of American showed that most of them worked with accept categories. Receiving compliments by saying, "thank you" due to express of openness and receiving appreciation from the interlocutor.

This study also elicits that the two groups had different preferences. Compliment responses were expressed by Indonesians who used various reasons; in this category they use indirect compliment responses. On other side, Americans with direct verbal responses were categorized with direct compliment responses. The research is, therefore, significant because to know the responses that must be used appropriately according to cultural background. It actually should not use freely.

\section{REFERENCES}

Allami, H., \& Montazeri, M. (2012). A Sociopragmatic Analysis of Compliment Responses in Persian. Iranian Journal of Applied Lkanguage 
114 Celt: A Journal of Culture, English Language Teaching \& Literature, Volume 20, Number 1, June 2020, pp. 96 - 116

Studies, 4(1), 1-38. $\quad$ Retrieved from http://ijals2.usb.ac.ir/article_1346_235.html

Annatius, V. (2005). A PRAGMATIC ANALYSIS OF COMPLIMENTS IN ZULU by. (December).

Austin, J. L. (1962). How to Do Things with Words: Second Edition. In Oxford At the Clarendon Press. https://doi.org/10.1093/acprof:oso/9780198245537.001.0001

Barkindo, S., Partial, I. N., Of, F., Language, E., \& Studies, L. (2013). a Pragmatic Analysis of Compliments in Hausa Social Contexts By the Requirements for the Award of Master'S Degree in.

Blum-kulka, S., \& Olshtain, E. (1984). Requests and apologies: A crosscultural study of speech act realization patterns (CCSARP). Applied Linguistics. https://doi.org/10.1093/applin/5.3.196

Brown, P., \& Levinson, S. C. (1988). Politeness: Some Universals in Language Usage (Studies in Interactional Sociolinguistics 4). TESOL Quarterly, 22(4), 660. https://doi.org/10.2307/3587263

Falasi, H. Al. (2007). Just say Thank you : A study of compliment responses. The Linguistics Journal, 2(1), 28-42.

Fujimura-wilson, K. (1991). A Cross-Cultural Study of Compliments and Compliment Responses in Conversation. 19-36.

Geert hofstede, Gert Jan Hofstede, M. M. (2010). Cultures and Organizations. In Cultures and Organizations. https://doi.org/10.1007/s11569-0070005-8

Golato, A. (2002). German compliment responses. Journal of Pragmatics. https://doi.org/10.1016/S0378-2166(01)00040-6

Herbert, R. (1988). The ethnography of English compliment and compliment responses. https://doi.org/10.1075/pbns.3.05her

Herbert, R. K. (1990). Sex-based differences in compliment behavior. Language in Society. https://doi.org/10.1017/S0047404500014378

Holmes, J. (1986). Compliments and Compliment Responses in New Zealand English. Anthropological Linguistics. 
Holmes, J. (1988). Paying compliments: A sex-preferential politeness strategy. Journal of Pragmatics. https://doi.org/10.1016/0378-2166(88)90005-7

Kochman, T. (1981). Black and White Styles in Conflict. Chicago: The University of Chicago Press.

Lorenzo-Dus, N. (2001). Compliment responses among British and Spanish university students: A contrastive study. Journal of Pragmatics. https://doi.org/10.1016/S0378-2166(99)00127-7

Maulida, N. (2019). TINDAK TUTUR MEMUJI DALAM FILM KAZE TACHINU. LITE, 15 nomor 1, 17.

Muhammad, A. A. (2013). KESADARAN HUKUM MASYARAKAT KAMPUNG MAHMUD UNTUK MEMILIKI SERTIFIKAT ATAS HAK ULAYAT: Studi Kasus di Kampung Adat Mahmud Desa Mekarrahayu Kecamatan Marga Asih Kabupaten Bandung. Universitas Pendidikan Indonesia.

Nobuyuki honna; Bates Hoffer. (1989). An english dictionary of japanese ways of thinking. Tokyo: Yuhikaku Publishing Co.

Pomerantz, A. M. (1978). Compliment responses: Notes on the co-operation of multiple constraints. In Studies in the organization of conversational interaction.

Rachman, A. K., \& Kinanti, K. P. (2018). Respon Pujian Oleh Mahasiswa Multikultural (Studi Kasus dengan Tinjauan Sosiopragmatik). Belajar Bahasa: Jurnal Ilmiah Program Studi Pendidikan Bahasa E Sastra Indonesia, $3(1)$.

Razi, N. (2013). A Contrastive Study of Compliment Responses among Australian English and Iranian Persian Speakers. Procedia - Social and Behavioral Sciences. https://doi.org/10.1016/j.sbspro.2013.01.038

Refnaldi. (2009). Transfer Pragmatik Dalam Respon Terhadap Pujian Dari Bahasa Indonesia Ke Dalam Bahasa Inggris. Linguistik Indonesia.

Sacks, H., \& Schegloff, E. (1973). Opening up closings. Semiotica.

Searle, J. R. (1976). A classification of illocutionary acts. Language in Society. https://doi.org/10.1017/S0047404500006837 
116 Celt: A Journal of Culture, English Language Teaching \& Literature, Volume 20, Number 1, June 2020, pp. 96 - 116

Thomas, J. (1983). Cross-cultural pragmatic failure. Applied Linguistics. https://doi.org/10.1093/applin/4.2.91

Vaneva, M., \& Ivanovska, M. (2018). Pragmatics of English Speech Acts: Compliments Used by Macedonian Learners. International Journal of English Linguistics, 8(5), 272. https://doi.org/10.5539/ijel.v8n5p272

Wierzbicka, A. (2003). Cross-Cultural Pragmatics: The Semantics of Human Interaction. In Language (2nd ed., Vol. 72). https://doi.org/10.2307/416282

Wolfson, N., \& Manes, J. (1980). The compliment as a social strategy. Paper in Linguistics. https://doi.org/10.1080/08351818009370503 